\title{
EU Market Access and Export Performance of Transition Countries
}

\section{Joze P. Damijan , Matija Rojec}

\begin{abstract}
A remarkable upgrading of export performance and a major re-orientation of foreign trade in favour of the EU-15 have been among the most outstanding features of the transition and EU integration processes of former socialist countries from Central, Eastern and South East Europe. This paper looks at the importance of (EU) market access for the upgrading of the export performance of these countries. Based on the empirical approach of Redding and Venables (2003, 2004), and Fugazza (2004), it was found that market access growth represents the main determinant of export growth for transition countries. Additionally, the importance of foreign market access growth for the export growth of transition countries is constantly increasing. Market access growth, in the case of both the NMS-8 (Czech Republic, Estonia, Hungary, Latvia, Lithuania, Poland, Slovakia and Slovenia) and most of the CC-3 (Bulgaria, Romania and Croatia) occurred predominantly within the EU-15. Better EU-15 market access can largely explain the better export performance of the NMS-8 in comparison to other transition countries.
\end{abstract}

Key words: Export performance, Transition countries, (EU) market access, Supply capacity

JEL : F120, F150, F210, 0100, P300

$10.2478 / \mathrm{v} 10033-007-0003-3$

\section{Introduction}

A remarkable upgrading of export performance and a major re-orientation of foreign trade in favour of the EU-15 have been among the most outstanding features of the transition and EU integration processes of former socialist countries from Central, Eastern and South East Europe. Since the beginning of the 1990s, most European transition countries recorded extremely high growth in exports in absolute as well as relative terms, accompanied by increasing market shares abroad, especially in the EU-15, and an increasing domination of the EU-15 as a market for exports. The analysis distinguishes between three groups of transition countries, i.e. the eight countries which entered the EU in 2005 (new member states, NMS-8: Czech Republic, Estonia, Hungary, Latvia, Lithuania, Poland, Slovakia and Slovenia), the two countries which entered the EU in 2007 plus Croatia (candidate countries, CC-3: Bulgaria, Croatia and Romania') , and three South-East European countries (South East Europe countries, SEE-3: Albania, Macedonia, and Serbia and
Montenegro ${ }^{2}$.

The following are the main features of increasing export performance and changes to the foreign trade of transition countries (see Table 1 for details):

- In 1991-2004, the exports of the NMS-8 increased by $648 \%$ and of the CC -3 by $382 \%$. The corresponding

\footnotetext{
* Joze P. Damijan

University of Ljubljana - Faculty of Economics; Vienna University of Economics and Business Administration; LICOS, KU Leuven; and Institute of Economic Research, Ljubljana (+386-1-5303-822, joze.damijan@ef.uni-lj.si)

* Matija Rojec

University of Ljubljana - Faculty of Social Sciences; and Institute of Macroeconomic Analysis and Development, Ljubljana (+386-1-478-1003, matija.rojec@gov.si)
} 


\begin{tabular}{|c|c|c|c|c|c|c|c|c|c|c|c|c|c|c|}
\hline & 1991 & 1992 & 1993 & 1994 & 1995 & 1996 & 1997 & 1998 & 1999 & 2000 & 2001 & 2002 & 2003 & 2004 \\
\hline EU - 15 & & & & & & & & & & & & & & \\
\hline Exports of goods (in EUR) & 1201850 & 1224991 & 1247462 & 1396704 & 1572823 & 1665205 & 1856468 & 81944269 & 92033628 & 2411635 & 2473163 & 32481826 & 2453286 & 2639310 \\
\hline Imports of goods (in EUR) & 1232648 & 1235180 & 1183345 & 1319305 & 1476558 & 1547433 & 1720310 & 1835065 & 51969006 & 2394873 & 2398083 & 32358467 & 2351142 & 2564615 \\
\hline Exports index $(1991=100)$ & 100 & 102 & 104 & 116 & 131 & 139 & 154 & 162 & 169 & 201 & 206 & 207 & 204 & 220 \\
\hline Exports as $\%$ of GDP & 20,5 & 20,0 & 20,3 & 21,7 & 23,4 & 23,6 & 25,0 & 25,1 & 24,9 & 27,7 & 27,4 & 26,5 & 25,8 & 26,6 \\
\hline Exports as $\%$ of World imports & 41,1 & 41,1 & 38,1 & 38,0 & 39,4 & 38,5 & 37,2 & 38,8 & 37,2 & 33,6 & 34,7 & 35,4 & 36,1 & 35,5 \\
\hline NMS-8 & & & & & & & & & & & & & & \\
\hline Exports of goods (in EUR) & 32297 & 34754 & 44575 & 52126 & 61703 & 66691 & 81696 & 94109 & 98759 & 129082 & 148053 & 159724 & 173113 & 209205 \\
\hline Imports of goods (in EUR) & 33434 & 38385 & 53204 & 61424 & 74031 & 89023 & 108974 & 122628 & 127081 & 162833 & 179233 & 189009 & 200259 & 235201 \\
\hline Exports index $(1991=100)$ & 100 & 108 & 138 & 161 & 191 & 206 & 253 & 291 & 306 & 400 & 458 & 495 & 536 & 648 \\
\hline Exports as \% of GDP & n.a. & n.a. & n.a. & n.a. & 29,3 & 27,9 & 30,3 & 32,4 & 32,5 & 36,7 & 37,4 & 37,8 & 41,5 & 46,0 \\
\hline Exports as \% of World imports & 1,11 & 1,17 & 1,36 & 1,42 & 1,54 & 1,54 & 1,64 & 1,88 & 1,80 & 1,80 & 2,08 & 2,28 & 2,55 & 2,81 \\
\hline Exports to EU- 15 as \% of EU- 15 imports & 1,54 & 1,75 & 2,14 & 2,34 & 2,53 & 2,53 & 2,87 & 3,34 & 3,47 & 3,69 & 4,19 & 4,57 & 4,94 & 5,38 \\
\hline Exports to EU-15 as \% of total exports & 58,9 & 62,2 & 56,8 & 59,2 & 60,6 & 58,8 & 60,4 & 65,1 & 69,1 & 68,4 & 67,8 & 67,5 & 67,1 & 65,9 \\
\hline CC-3 & & & & & & & & & & & & & & \\
\hline Exports of goods (in EUR) & 8766 & 9771 & 10588 & 12117 & 13854 & 13955 & 15503 & 15264 & 15747 & 21344 & 23647 & 25925 & 27750 & 33372 \\
\hline Imports of goods (in EUR) & 9793 & 11649 & 13267 & 13891 & 18134 & 19393 & 22414 & 22471 & 22397 & 29909 & 35744 & 38617 & 43358 & 51242 \\
\hline Exports index $(1991=100)$ & 100 & 111 & 121 & 138 & 158 & 159 & 177 & 174 & 180 & 243 & 270 & 296 & 317 & 381 \\
\hline Exports as $\%$ of GDP & n.a. & n.a. & n.a. & n.a. & n.a. & n.a. & n.a. & 22,8 & 23,8 & 21,3 & 25,9 & 26,4 & 26,9 & 25,7 \\
\hline Exports as \% of World imports & 0,30 & 0,33 & 0,32 & 0,33 & 0,35 & 0,32 & 0,31 & 0,30 & 0,29 & 0,30 & 0,33 & 0,37 & 0,41 & 0,45 \\
\hline Exports to EU-15 as \% of EU- 15 imports & 0,28 & 0,32 & 0,38 & 0,45 & 0,47 & 0,45 & 0,46 & 0,47 & 0,46 & 0,52 & 0,61 & 0,68 & 0,74 & 0,78 \\
\hline Exports to EU-15 as \% of total exports & 38,9 & 40,5 & 42,9 & 48,6 & 50,1 & 50,2 & 51,1 & 56,2 & 57,9 & 58,4 & 61,5 & 61,5 & 62,3 & 60,0 \\
\hline SEE-3 & & & & & & & & & & & & & & \\
\hline Exports of goods (in EUR) & n.a. & n.a. & n.a. & n.a. & n.a. & 2664 & 3575 & 3872 & 2837 & 3551 & 3732 & 3943 & 3953 & 4893 \\
\hline Imports of goods (in EUR) & n.a. & n.a. & n.a. & n.a. & n.a. & 5274 & 6376 & 6741 & 5831 & 7411 & 8760 & 10360 & 10690 & 13305 \\
\hline Exports index $(1996=100)$ & n.a. & n.a. & n.a. & n.a. & n.a. & 100 & 134 & 145 & 107 & 133 & 140 & 148 & 148 & 184 \\
\hline Exports as \% of GDP & n.a. & n.a. & n.a. & n.a. & n.a. & n.a. & 16,2 & 19,4 & 12,3 & 10,4 & 17,3 & 15,7 & 14,5 & 16,3 \\
\hline Exports as \% of World imports & n.a. & n.a. & n.a. & n.a. & n.a. & 0,06 & 0,07 & 0,08 & 0,05 & 0,05 & 0,05 & 0,06 & 0,06 & 0,07 \\
\hline Exports to EU-15 as \% of EU- 15 imports & n.a. & n.a. & n.a. & n.a. & n.a. & 0,17 & 0,21 & 0,21 & 0,14 & 0,15 & 0,16 & 0,17 & 0,17 & 0,19 \\
\hline Exports to EU-15 as \% of total exports & n.a. & n.a. & n.a. & n.a. & n.a. & 40,4 & 40,5 & 42,4 & 46,3 & 43,6 & 49,3 & 48,6 & 50,5 & 50,1 \\
\hline
\end{tabular}

\section{Table 1.}

MAIN EXPORT-RELATED INDICATORS OF NMS-8, CC-3, SEE-3, AND EU-15 IN 1991-2004

(in mill. EUR, current prices and \%)

Sources: UNCTAD, World Bank and WIIW (The Vienna Institute for International Economic Studies) databases.

Note: NMS-8: Czech Republic, Estonia, Hungary, Latvia, Lithuania, Poland, Slovakia and Slovenia;

CC-3: Bulgaria, Croatia and Romania; SEE-3: Albania, Macedonia, and Serbia and Montenegro

increase in the EU-15 was 220\%. Over the shorter period of 1996-2004, the exports of the SEE-3 increased by $184 \%$. The export increase of the CC-3 and in particular of the NMS-8 was much higher over the same period.

- The increase in the exports of transition countries resulted directly from a considerable increase in their market shares abroad, especially in the EU-15. In 19912004, the share of NMS-8 exports to the EU-15 in terms of total EU-15 imports increased from $1.54 \%$ to $5.38 \%$, and for the CC-3, from $0.28 \%$ to $0.78 \%$. In 1996-2004, market shares of the SEE-3 in the EU-15 remained almost unchanged (it increased from $0.17 \%$ to $0.19 \%$ ). The market shares of the NMS- 8 and the CC-3 in the EU-15 recorded a very high increase over the same period.

- All of this points to the growing importance of EU-15 markets for the exports of transition countries. In 2004, the EU-15 absorbed as much as $65.9 \%$ of total NMS-8 exports (in 1991 58.9\%), 60.0\% of total CC-3 exports
(38.9\% in 1991) and $50.1 \%$ of total SEE-3 exports (in 1996, 40,4\%). The situation with imports is similar.

- All of this points to considerable export intensification for the NMS-8 measured by an export to GDP ratio (increasing from 29.3\% in 1995 to $46.0 \%$ in 2004). The level and pace of export intensification of the CC-3 has been much lower (25.7\% in 2004), while the export intensity of SEE-3 stagnated at an even lower level (approximately 16\%).

We use the term 'candidate countries' because Bulgaria and Romania were not yet EU member states at the time of the analysis.

2 In terms of economic performance and the transition process, the SEE-3 clearly lag behind the CC-3 (see EBRD 2005, for example). The SEE-3, however, are at a rather different stage in the EU integration process: Macedonia is a candidate country, Albania concluded the Stabilisation and Association Agreement with the EU in 2006, while Serbia and Montenegro is only at the negotiation stage of this agreement. In addition, Serbia and Montenegro recently split into two independent states. In the analysis, the two countries are treated as one because they were a single state at the time the data was collected. 
The above trends demonstrate rapid, strong growth and the increasing importance of the EU for the foreign trade of transition countries. In all countries, the trends and structural changes progress in the same direction, but significantly vary between different groups of countries. As expected, this process is by far the fastest and the strongest in the NMS-8. These countries demonstrate rapid progress in all the analysed aspects of export competitiveness. The CC-3 show similar trends, but the progress is much slower. The SEE-3 also increased their exports, but lag behind considerably in terms of volume as well as the dynamics of their foreign trade. Their market shares in the EU-15, and the export intensity of their economies (export to GDP ratios), have remained almost unchanged since 1996.

The objective of the paper is to analyse the role of changes in EU market access, i.e. European integration, in the impressive growth of the export performance among transition countries. Based on the relevant theoretical concepts, we follow the approach of Redding and Venables $(2003,2004)$, and Fugazza (2004) and distinguish between market access and supply capacity determinants of export performance. More precisely, we build an econometric model to assess the contribution of market access (in general and to the EU15) versus supply capacity improvement to increasing the export performance of transition countries. Following the gravity approach, the proximity and size of the EU market, in addition to the EU integration process, are rather selfevident factors contributing to the improved EU market access for transition countries. In this framework, it is not our ambition to disentangle the impact of the basic factors of a gravity model (size of trading countries, their proximity, historical/cultural/language proximity) from the impact of institutional factors (timing and types of institutional arrangements of $\mathrm{EU}$ integration process) on EU market access. This is beyond the reach of the available data set. The focus of our study is more on whether there are any significant differences in the contribution of EU market access to the export performance of the three groups of transition countries. In this way, we broaden the existing analysis of market access versus the supply capacity factors of the export performance of transition countries by Redding and Venables $(2003,2004)$ and Fugazza, in three directions: (i) by increasing the number of transition countries examined, (ii) by dividing the countries into three groups (NMS-8, CC3, SEE-3), differentiated by level of development, export performance and status within the EU integration process, and (iii) by updating the period analysed to 2004 .
The paper is structured as follows. Section 2 analyses the theoretical and empirical context of the growing export performance of transition countries. Section 3 analyses the existing literature on the improved access of transition countries to EU markets. In Section 4 we build an econometric model for assessing the relevance of market access and supply capacity for the export performance of transition countries and present our results. Section 5 presents our conclusions..

\section{Growing Export Performance of Transition Economies in Theoretical and Empirical Contexts}

The existing literature on export performance tends to distinguish between factors determining market access and factors determining the supply capacity of exporting countries. As far as market access is concerned, the gravity theory presents the most powerful explanatory tool. The opening up of European transition economies seems to be the most important factor in their improved export performance, simply because it enabled gravity forces - proximity of and integration in the large and high purchasing power EU markets - to act and to make the EU-15 their main market. The supply capacity factors of export performance can be explained by comparative advantages arising from different factor intensities/endowments and/or by economies of scale in (horizontal) intra-industry trade characterized by similarities in technology and quality standards. Both theoretical approaches are relevant for the explanation of the export performance of transition countries because, as shown by the data, the main part of the trade of transition countries is still inter-industry trade and vertical intra-industry trade, though the share of horizontal intra-industry trade is slowly increasing. More horizontal intra-industry trade will only gradually outweigh trade based on comparative advantages.

The literature dealing with the increasing export perfor-

Factors determining the supply capacity are numerous - overall export potential of the exporting country expressed by GDP and GDP per capita, productivity level, level of technological development, FDI, real exchange rate, institutional changes (see Redding and Venables 2003, 2004, Fugazza 2004, Rojec and Ferjančič 2006) - yet we do not analyze these, as our primary interest is the role of EU market access. 
mance of transition countries ranges from gravity models, upgraded gravity models, distinguishing between market access and supply capacity factors, shift share analysis, analysis of (export) competitiveness and more or less comprehensive descriptive analysis of factors behind growing export performance.

By far the most popular approach to the analysis of the export performance of transition countries is that inspired by the gravity theory (Collins and Rodrik, 1991; Havrylyshyn and Pritchett, 1991; Rosati, 1992; Hamilton and Winters, 1992; Baldwin, 1994; Kaminski, Wang and Winters, 1996a; Jakab, Kovacs and Oszlay, 2001; Havrylyshyn and Al-Atrash, 1998; Egger, 2003; Fidrmuc and Fidrmuc, 2003; Bussiere, Fidrmuc and Schantz, 2005). The gravity models ${ }^{4}$ suggest that, with the lifting of central planning restrictions on foreign trade, the transition to market economies and the independence of new countries have led to an increase and geographical restructuring in foreign trade along the lines of the gravity theory, i.e. the foreign trade intensity of transition countries increased to a major extent, and the EU-15, as a large, nearby, highly developed market, assumed the role of the dominant trading partner. Transition countries gradually approach the »normal« level of their trade with developed countries, especially the EU, but there are considerable differences between individual countries.

\begin{tabular}{|c|c|c|c|c|c|}
\hline Period & 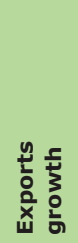 & 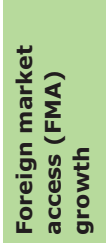 & 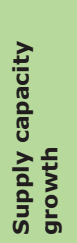 & 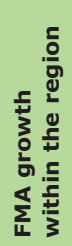 & 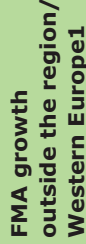 \\
\hline \multicolumn{6}{|c|}{ FUGAZZA: Eastern Europe and Central Asia2 } \\
\hline $1980-87$ & 9 & -2 & 7 & -17 & -1 \\
\hline 1984-91 & 23 & 31 & 34 & 30 & 31 \\
\hline $1988-95$ & 4 & 80 & -90 & 117 & 79 \\
\hline 1992-99 & 66 & -9 & 48 & 5 & -9 \\
\hline
\end{tabular}

REDDING AND VENABLES: Eastern Europe3

\begin{tabular}{|l|c|c|c|c|c|}
\hline M1970/73-1994/97 & 187 & 95 & 40 & 3 & 61 \\
\hline $1970 / 73-1982 / 85$ & 44 & 34 & 11 & 0 & 18 \\
\hline $1982 / 85-1994 / 97$ & 100 & 45 & 26 & 3 & 32 \\
\hline
\end{tabular}

Table 2.

Components of Export Growth in Transition Countries included in Fugazza (2004) and Redding and Venables (2003)

Notes: 1/ 'Outside the region' in the case of Fugazza and

'Western Europe' in the case of Redding and Venables;

2/ Hungary, Poland, Romania, Bulgaria and Turkey;

3/ Albania, Bulgaria, Czechoslovakia, Hungary, Poland, Romania
Redding and Venables (2003, 2004), and on their basis Fugazza (2004), developed a model of trade which uses gravity techniques to estimate to what extent the export growth of a country is due to changed access to foreign markets and to what extent it is due to changes in the internal supply capacity of the exporting country. The internal supply capacity is regressed to variables such as GDP, population, internal transport costs and one or two institutional variables (real exchange rate fluctuations, risk of expropriation, labour market characteristics). Table 2 shows that, overall, market access has been more important than supply capacity for improving the export performance of transition countries. In Redding and Venables (2003), foreign market access growth was a much more important source of export growth than supply capacity growth. The main component of foreign market access growth was Western Europe (i.e. EU). Still, the actual level of trade of Eastern Europe is lower than one would expect considering its good market access and better than average internal geography and institutions. This is because transition countries are faced with supply capacity constraints. The results of Fugazza are more ambiguous. In the first phase of transition (1988-95), foreign market access was much more important for the export growth of transition countries than supply capacity growth, while the situation in 1992-99 was quite the opposite. It is more or less obvious that the beginning of transition was characterized by the opening of the markets in EU and elsewhere, while defensive enterprise restructuring (elimination of non-viable companies and production programs) reduced the supply capacity.

Other approaches to the analysis of the export performance of transition economies include:

- Shift-share analysis, which decomposes the overall increase in exports into a general demand component, a structural effect component and a competitive effect component. Havlik, Landesmann and Stehrer (2001) demonstrate that transition countries considerably improved their competitive position

\footnotetext{
In gravity models, trade between two countries is positively related to each country's economic size and development level, and negatively to the distance between them, the latter determining transport costs (Rivera-Batiz and Olive, 2003, pp. 99-102). Size determines the supply conditions in the source country and the demand conditions in the host country. Other factors, which influence the magnitude of bilateral trade, like common language, if two countries were part of the same territory, common borders, free trade arrangement, are also commonly included in the model (Bussiere. Fidrmuc and Schantz, 2005: 14-15).
} 
(competitive effect component) in the EU-15 compared to non-EU competitors.

- Synthetic index of export performance, composed of (i) the change in the dollar value of exports, (ii) the change in the share of CMEA (Council for Mutual Economic Assistance) countries in total exports, (iii) the percentage increase in manufactured exports to OECD, (iv) the ratio of OECD-oriented manufactured exports to GDP. Kaminski, Wang and Winters (1996b) claim that speed and scope of transition reforms have been more important than initial conditions and market access in explaining inter-country differences in export performance.

- (Export) competitiveness analysis (Halpern, 2002; IMD, 2004; Zinnes, Eilat and Sachs, 2001; Havlik, 2000) of transition economies suggests positive contribution of supply capacity factors to CEEC's export performance.

\section{Improved Access of CEEC to EU Markets}

One of the most outstanding features of the export performance of transition countries from the beginning of transition is the increasing importance of EU-15 as the main market of their exports. Most of this development is explained by gravity theory, i.e. by the fact that pre-transition trade within CMEA countries was well above the 'normal' level and with the EU-15 well below the 'normal' level. The size, proximity and development level of the EU-15 are extremely strong gravity forces for the exports of transition countries. Additionally, the EU integration process has provided these countries with preferential access to EU-15 markets. How important has been this institutional factor? The fact that all three analyzed groups of transition countries considerably increased their market shares in the EU-15 suggests that preferential access to EU-15 markets has produced the anticipated effects. Unfortunately, to our knowledge, no econometric estimation of the subject has been done so far $^{5}$. The literature suggests that preferential market access, especially the Europe Agreements, has clearly been important for increasing the volume of trade in transition countries, but has not been directly responsible for much of the growth of their exports (Kaminski, Wang and Winters, 1996b: 34). This is because the scope of preferential treatment has been limited by a number of inherent limitations (antidumping procedures, tight rules of origin, delays in liberalizing the import of sensitive products) while other basic factors of export performance have been more important for export expansion. Because of this, transition countries with basically the same scope of preferential access to the EU-15 perform differently in terms of their exports.

The access of transition countries to OECD/EU markets has evolved in three stages. The first stage was the removal of discriminatory measures (non-tariff barriers) aimed specifically against state trading economies, and the granting of MFN status. The EU was the first to do this. The second stage was granting of preferential market access under the General System of Preferences (GSP), which put transition countries on par with developing countries with quota limited free access for most products. Again the EU was the first to do this. The third stage was the signing of Europe Agreements between the EU-15 and the NMS-8 by the mid-1990s (Poland, the former Czechoslovakia and Hungary in 1991, Estonia, Latvia and Lithuania in 1995, and Slovenia in 1996), and their anticipated accession to the EU after the Copenhagen EU summit (Kaminski, Wang and Winters, 1996b). Romania and Bulgaria signed Europe Agreements in 1993. The other countries we will analyze signed Stabilisation and Association Agreements ${ }^{6}$ : Croatia and Macedonia in 2001, Albania in 2006, while Serbia and Montenegro are still in negotiations. In 2000, the EU granted autonomous trade measures to the countries of the Western Balkans, including Albania, Croatia, Macedonia, and Serbia and Montenegro,

\footnotetext{
$5 \quad$ Recent analysis of Mongelli, Dorrucci and Agur (2005) partly deals with this issue, although it is not directly related to the EU accession process. They investigate the link between economic integration and the overall institutional process of regional integration in Europe. The evidence suggests that the interaction between regional institutional and trade integration is significant. Such interaction runs in both directions, but the link from institutional to trade integration dominates

6 A Stabilisation and Association Agreement has practically the same coverage as a Europe Agreement, plus it adds special emphasis to the promotion of regional cooperation (creation of a network of free trade agreements of SEE countries, recently upgraded into their membership in CEFTA) and political stability.

7 On January 27, 2006, the Commission published a Communication "The Western Balkans on the road to the EU: consolidating stability and raising prosperity" in which it lays down, inter alia, policy proposals to foster trade, like the rapid conclusion of the regional Free Trade Agreement between the countries of the region, and establishing a zone of diagonal cumulation of origin between the EU and the countries of region that have concluded free trade agreements with the EU.
} 
making it possible for all their exports to enter the EU free of duties and any quantitative limits. In 2005, these autonomous trade concessions were extended until $2010^{7}$.

According to Kaminski, Wang and Winters (1996b: 33), the GSP represented a big step in tariff liberalization ${ }^{8}$, but there is little evidence that, "with its limitations and exclusions (quantity limits, special treatment of sensitive products, uncertainty of access), it alone can explain changes in transition economies shares in OECD imports." Clearly, Europe Agreements have been more important than GSP. Kaminski (1994) analyzed the effects of Europe Agreements with Czechoslovakia, Hungary, Poland, Romania and Bulgaria signed in 1991 and 1992. He claims that provisions on trade with industrial products, which affected about $80 \%$ of the exports of the five countries to the EU, significantly improved their access to EU markets. In 1992, the first year they were in force in Hungary, Poland and the former Czechoslovakia, the Agreements freed slightly less than $50 \%$ of total exports to the EU from import duties and nontariff barriers. According to the Agreements, these shares were to increase over five years to about $80 \%$ for the former Czechoslovakia, 60\% for Hungary and 70\% for Poland. In addition, tariffs were reduced for a number of other products, and the Copenhagen summit further cut the time to reach the top of the EU preferential trade pyramid, which was then occupied by EFTA countries. These reductions translated into a competitive edge over suppliers from other countries. Still, the Europe Agreements retained a number of restrictions characteristic for GSP (delays in liberalizing imports of sensitive products, tight rules of origin, continuing threats of antidumping and the virtual exclusion of agriculture), which were removed only gradually in the process of EU integration.

\section{Accounting for the Contribution of Market Access Versus Supply Capacity Improvement to Export Performance}

In this section we assess the contribution of foreign market access versus internal supply capacity improvement to the export growth of individual transition countries. This approach consists of two steps. In the first step, we quantify the respective roles of foreign market access and supply capacity as two key determinants of the export performance of a given country. In the second step we then use the esti- mates obtained in the first stage of the analysis in order to construct supply capacity and foreign market access series. These serve as an analytical tool to reveal the importance of foreign market access and of the supply capacity of the home economy for a country's export performance.

\subsection{Decomposition of Export Performance}

Total export growth can be decomposed into supply capacity and foreign market access growth. Following the approach of Redding and Venables $(2003,2004)$ and Fugazza (2004), we estimate a gravity model equation where the dependent variable is exports (logarithm) from country i to

$$
\text { (1) } \quad \ln X_{i j}=\alpha+\beta_{j} \text { Partner }_{j}+\gamma_{i} \text { Country }_{i}+\delta_{1} \text { Dist }_{i j}+\delta_{2} \text { Bord }_{i j}+u_{i j}
$$

country j and the dependent variables are bilateral distance (logarithm), an indicator of the existence of a common border, exporter-country dummies and importer-partner dummies:

Bilateral distance Dist and the border dummy Bord ${ }_{i j}$ are assumed to capture geographical bilateral trade costs. Exporters and importer partners fixed effects, Country, and Partner, respectively, are introduced to control for supplier capacity and market capacity. These terms can also serve as a control for institutions and policy related bilateral trade costs.

The model is estimated for 14 transition countries (NMS-8, CC-3, SEE-3) at the level of aggregate trade flows of these countries with their most important trading partners from all over the world. The data set spans over the period 1994 2004, which makes a balanced panel for 11 years. Bilateral trade flows, distance measures and GDP data are obtained from WIIW and CEPII databases.

The model (1) is estimated year-by-year in order to allow for annual variations in estimated individual parameters of interest. A simple OLS estimator is used in these exercises. Results are presented in Table 3. Estimated coefficients of

8 At the time of its introduction for transition countries, MFN tariffs on industrial products in the EU averaged around $6 \%$, whereas average GSP tariffs were around $2 \%$, and most of GSP items (94\%) were subject to zero rates. $74 \%$ of tariff lines of industrial products had zero rates (Kaminski, Wang and Winters, 1996b: 34).

9 Note that in a previous version of estimations without the SEE-3 the distance coefficients were of the same magnitude as in the Fugazza study and have doubled only after including the SEE- 3 into the sample. This indicates higher trade costs (transport cost, tariffs, etc.) in trade with these countries. 
geographical distance are twice those obtained by Fugazza (2004) with a larger and more heterogenous data set, which means that the trade flows between the old EU-15, new member states and other transition countries in our sample are comparatively more affected by trade costs 9 . There is not much variation in estimated coefficients over time, indicating the robust importance of transport costs for the export performance of individual countries. On the other hand, the coefficients for border dummies are about half the size of those obtained by Redding and Venables (2003) and Fugazza (2004) and decreasing over time. This indicates the importance of cross-border trade for transition countries, which diminished with the economic integration and economic development of these countries over the last decade. With closer integration into the EU economic area, and with high rates of productivity growth, the relative im-

\begin{tabular}{|c|c|c|c|c|c|c|c|c|c|c|c|}
\hline & 1994 & 1995 & 1996 & 1997 & 1998 & 1999 & 2000 & 2001 & 2002 & 2003 & 2004 \\
\hline \multirow[t]{2}{*}{ InDIST1 } & $* * *-1,384$ & $* * *-1,604$ & $* * *-1,674$ & $* * *-1,755$ & $* * *-1,573$ & $* * *-1,611$ & $* * *-1,549$ & $* * *-1,471$ & $* * *-1,602$ & $* * *-1,535$ & $* * *-1,441$ \\
\hline & $-7,42$ & $-8,49$ & $-9,63$ & $-9,65$ & $-9,06$ & $-9,83$ & $-9,51$ & $-9,5$ & $-10,29$ & $-10,06$ & $-9,94$ \\
\hline \multirow[t]{2}{*}{ Border } & 0,676 & 0,534 & 0,233 & 0,174 & 0,347 & 0,146 & 0,147 & 0,413 & 0,161 & 0,234 & 0,310 \\
\hline & 0,99 & 0,77 & 0,36 & 0,26 & 0,54 & 0,24 & 0,25 & 0,73 & 0,28 & 0,42 & 0,58 \\
\hline \multirow[t]{2}{*}{ CZ } & $* * * 5,526$ & $* * * 6,623$ & $* * * 5,982$ & $* * * 5,756$ & $* * * 6,196$ & $* * * 6,072$ & $* * * 5,761$ & $* * * 4,831$ & $* * * 4,760$ & $* * * 4,526$ & $* * * 4,306$ \\
\hline & 7,67 & 9,09 & 8,86 & 8,2 & 9,24 & 9,57 & 9,13 & 8,14 & 7,93 & 7,69 & 7,62 \\
\hline \multirow[t]{2}{*}{ EE } & $* * *-1,358$ & $-0,072$ & $-0,323$ & $-0,717$ & $* 0,892$ & $* * 1,075$ & 0,603 & $-0,283$ & $-0,067$ & $-0,589$ & $* * *-1,329$ \\
\hline & $-2,69$ & $-0,14$ & $-0,68$ & $-1,46$ & 1,90 & 2,42 & 1,36 & $-0,68$ & $-0,16$ & $-1,43$ & $-3,35$ \\
\hline \multirow[t]{2}{*}{ HU } & $* * * 5,308$ & $* * * 6,394$ & $* * * 5,658$ & $* * * 5,748$ & $* * * 6,172$ & $* * * 6,057$ & $* * * 5,657$ & $* * * 4,781$ & $* * * 4,675$ & $* * * 4,515$ & $* * * 4,300$ \\
\hline & 7,81 & 9,3 & 8,88 & 8,68 & 9,76 & 10,12 & 9,5 & 8,53 & 8,25 & 8,13 & 8,06 \\
\hline \multirow[t]{2}{*}{ LV } & $* * *-1,348$ & $*-0,855$ & $*-0,774$ & $-0,394$ & 0,685 & 0,252 & 0,291 & $-0,564$ & $* *-1,057$ & $-0,633$ & $*-0,783$ \\
\hline & $-2,61$ & $-1,64$ & $-1,60$ & $-0,78$ & 1,42 & 0,55 & 0,64 & $-1,32$ & $-2,45$ & $-1,50$ & $-1,93$ \\
\hline \multirow[t]{2}{*}{ PL } & $* * * 5,766$ & $* * * 6,849$ & $* * * 6,200$ & $* * * 6,136$ & $* * * 6,473$ & $* * * 6,578$ & $* * * 6,247$ & $* * * 5,311$ & $* * * 5,172$ & $* * * 5,054$ & $* * * 4,935$ \\
\hline & 8,16 & 9,59 & 9,37 & 8,93 & 9,85 & 10,58 & 10,11 & 9,13 & 8,79 & 8,76 & 8,91 \\
\hline \multirow[t]{2}{*}{ SK } & $* * 1,498$ & 0,808 & $* * * 4,683$ & $* * * 4,437$ & $* * * 4,814$ & $* * * 4,759$ & $* * * 4,409$ & $* * * 3,456$ & $* * * 3,317$ & $* * * 3,429$ & $* * * 3,233$ \\
\hline & 2,10 & 1,12 & 7,02 & 6,40 & 7,27 & 7,59 & 7,08 & 5,89 & 5,59 & 5,90 & 5,79 \\
\hline \multirow[t]{2}{*}{ SI } & $* * * 3,742$ & $* * * 5,386$ & $* * * 4,497$ & $* * * 4,505$ & $* * * 5,080$ & $* * * 4,990$ & $* * * 4,418$ & $* * * 3,439$ & $* * * 3,321$ & $* * * 3,328$ & $* * * 3,066$ \\
\hline & 5,64 & 8,03 & 7,23 & 6,98 & 8,23 & 8,54 & 7,61 & 6,29 & 6,01 & 6,14 & 5,89 \\
\hline \multirow[t]{2}{*}{ BG } & $* * * 3,166$ & $* * * 4,233$ & $* * * 3,378$ & $* * * 3,248$ & $* * * 3,389$ & $* * * 3,846$ & $* * * 4,099$ & $* * * 3,175$ & $* * * 3,055$ & $* * * 2,959$ & $* * * 2,745$ \\
\hline & 4,55 & 5,98 & 5,18 & 4,79 & 5,23 & 6,27 & 6,72 & 5,53 & 5,27 & 5,20 & 5,03 \\
\hline \multirow[t]{2}{*}{ CRO } & $* * * 3,627$ & $* * * 4,601$ & $* * * 3,978$ & 3,941 & $* * * 4,296$ & $* * * 4,101$ & $* * * 3,573$ & $* * * 2,712$ & $* * * 2,472$ & $* * * 2,353$ & $* * * 2,066$ \\
\hline & 5,37 & 6,73 & 6,28 & 5,99 & 6,83 & 6,89 & 6,04 & 4,87 & 4,39 & 4,26 & 3,90 \\
\hline \multirow[t]{2}{*}{ RO } & $* * * 4,618$ & $* * * 6,129$ & $* * * 4,932$ & $* * * 5,026$ & $* * * 5,174$ & $* * * 4,930$ & $* * * 4,665$ & $* * * 3,762$ & $* * * 3,682$ & $* * * 3,494$ & $* * * 3,372$ \\
\hline & 6,44 & 8,45 & 7,34 & 7,2 & 7,75 & 7,81 & 7,43 & 6,36 & 6,16 & 5,96 & 5,99 \\
\hline \multirow[t]{2}{*}{ ALB } & & $* * 2,519$ & & $* 2,120$ & $* * 2,059$ & & $* * *-2,896$ & & $* * *-3,195$ & & $* * *-3,506$ \\
\hline & & 2,19 & & 1,92 & 1,98 & & $-2,89$ & & $-3,40$ & & $-4,15$ \\
\hline \multirow[t]{2}{*}{ MK } & $* 2,000$ & $* * * 4,158$ & 1,567 & $* * * 4,410$ & $* * * 4,681$ & $* * 2,226$ & 0,366 & $* * * 2,409$ & $-1,008$ & $* * 2,009$ & $* *-1,775$ \\
\hline & 1,80 & 3,94 & 1,53 & 4,29 & 4,82 & 2,40 & $-0,40$ & 2,61 & $-1,16$ & 2,24 & $-2,19$ \\
\hline \multirow[t]{2}{*}{ SMN } & $-2,228$ & & $* *-2,526$ & & & $* * * 2,580$ & & $* * * 3,143$ & & $* * * 3,107$ & \\
\hline & $-1,94$ & & 2,37 & & & 2,64 & & 3,29 & & 3,32 & \\
\hline
\end{tabular}

Partner dummies

\begin{tabular}{|l|}
\hline EU-15 \\
\hline NMS-8 \\
\hline CC-3 \\
\hline OECD \\
\hline SEE-3 \\
\hline Const. \\
\hline No. of obs \\
\hline Adj R-sq. \\
\hline
\end{tabular}

\begin{tabular}{|r|r|r|r|}
\hline$* * * 4,649$ & $* * * 4,918$ & $* * * 4,315$ & $* * *$ \\
\hline 9,59 & 10,05 & 9,53 & \\
\hline$* * * 1,950$ & $* * * 2,185$ & $* * * 2,113$ & $* * *$ \\
\hline 3,23 & 3,59 & 3,75 \\
\hline$* * * 1,993$ & $* * * 2,302$ & $* 1,403$ & \\
\hline 2,43 & 2,78 & 1,82 \\
\hline 3,619 & $* * * 4,108$ & $* * * 4,140$ & $* * *$ \\
\hline 9,98 & 11,22 & 12,22 & \\
\hline$* * *-11,77$ & $* * *-13,09$ & $* * *-11,47$ & $* * *$ \\
\hline$-12,50$ & $-14,78$ & $-13,22$ & -12 \\
\hline$* * * 19,745$ & $* * * 20,200$ & $* * * 21,733$ & $* * * 2$ \\
\hline 12 & 12,12 & 14,19 & \\
\hline 1086 & 1088 & 1088 & \\
\hline 0,626 & 0,646 & 0,674 \\
\hline
\end{tabular}

***4,370 ***4,240

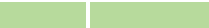

(1) . 
portance of transport costs might have decreased, allowing domestic firms to increasingly afford to bear the costs of shipping goods to non-neighbouring countries.

We introduce exporters and importer partners as fixed effects, Countryi and Partnerj, where the former serve to control for supplier capacity, and the latter for foreign market capacity. Home countries' (i.e. exporters) parameters are mostly significant and do reveal positive increasing trends over time, indicating a rise in domestic supply capacities in most of the countries. One should interpret the home countries' effect with respect to the coefficients of the constant term. Since the constant term is returning an average level of bilateral trade flows, the individual country coefficients therefore indicate an individual country's positive or negative deviations from the average level of trade flows. In this context, one can realize that smaller and/or less developed countries (such as the Baltic and South East European countries) do exhibit lower levels of trade flows. Importer dummies indicate the importance of individual regions in terms of their importance as foreign markets for the exports of individual countries. In accordance with the process of trade liberalization with the EU in the 1990s, the EU market dominates over other importer dummies. The importance of other OECD countries is about $80 \%$ of the EU markets, while the importance of trade with the NMS-8 and the CC-3 is only about $30 \%$ to $40 \%$ of the EU markets. As expected, coefficients for the SEE-3 foreign market dummy are significant and exhibit very high negative coefficients, indicating the very low revealed importer market potential of these countries compared to most of the transition countries.

\subsection{Accounting for Supply Capacity and Foreign Market Access}

In the second step, the estimates obtained in the first stage of the analysis (estimates from model (1)) are used to construct supply capacity and foreign market access series. The supply capacity estimate for country $\mathrm{i}(\mathrm{SCi})$ is given by the exponential of exporter country dummy times its coefficient:

$$
\text { (2) } S C_{i}=\exp \left(\gamma_{i} \text { Country }_{i}\right)
$$

While the foreign market access estimate (FMAi) is given by:

$$
\text { (3) } \quad F M A_{i}=\sum_{i \neq j} \exp \left(\hat{\beta}_{j} \text { Partner } r_{j}\right)^{*} \operatorname{Dist}_{i_{j}}^{t_{1} t^{2}} * \exp \left(\hat{\delta}_{2} \text { Bor }_{i j}\right)
$$
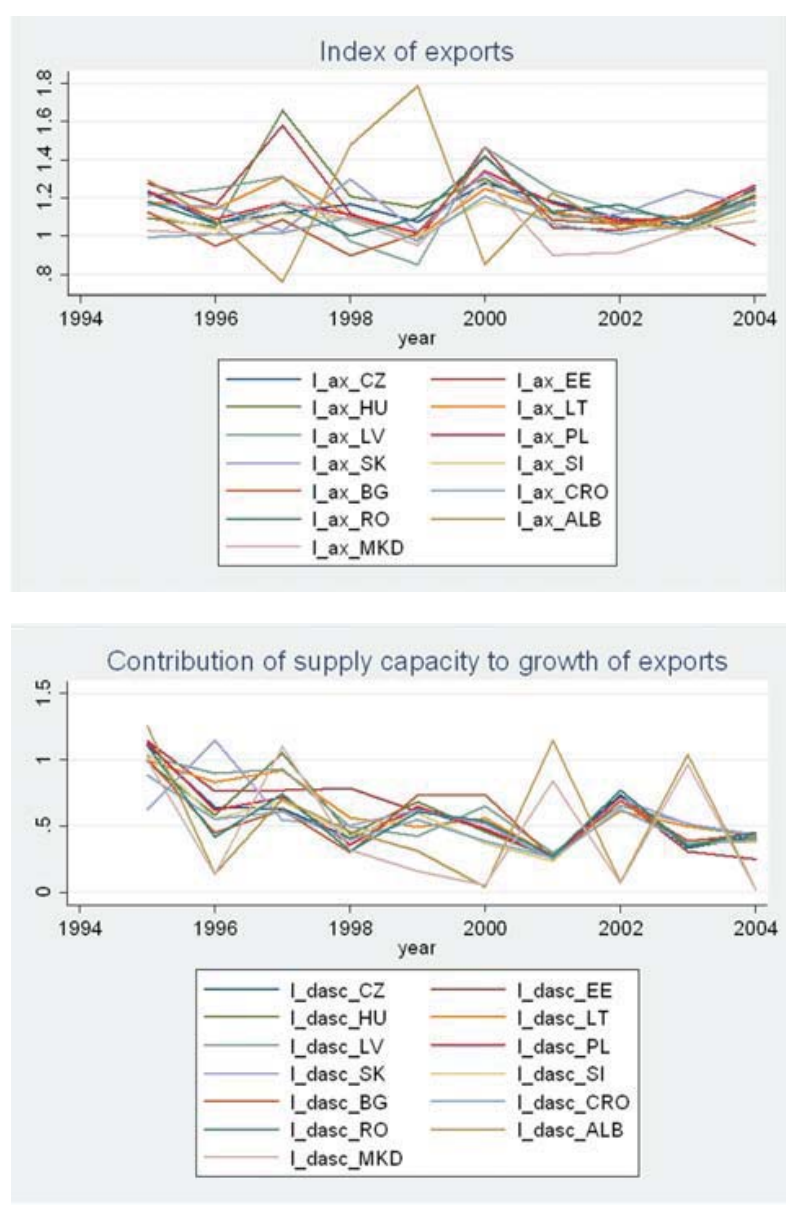

Contribution of foreign market access to growth of exports

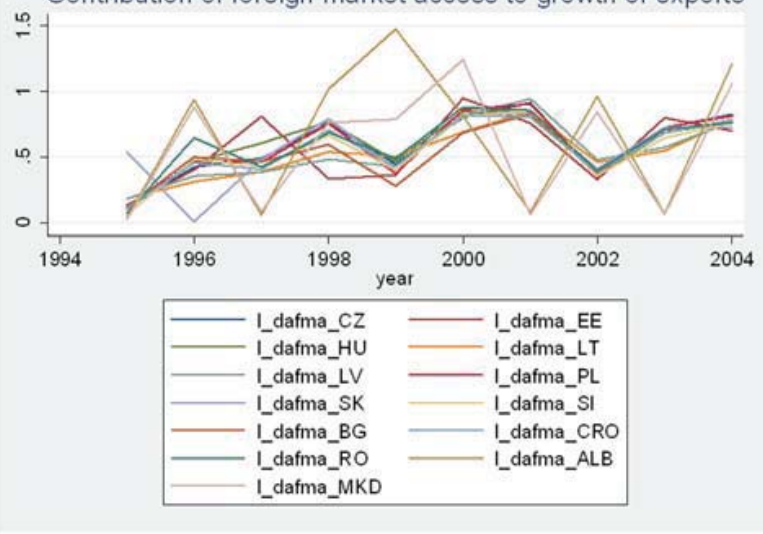

\section{Figure 1.}

Growth Index for Exports,

Supply Capacity and Foreign Market Access.

The estimates of supply capacity (2) and foreign market access (3) allow us to decompose the sources of export growth over the last decade and help us analyse over time the contributions of both the supply capacity as well as the foreign market access to the export performance of each individual transition country.

As revealed in Figure 1, the evolution of exports, supply ca- 


\begin{tabular}{|c|c|c|c|c|c|c|c|c|c|c|c|c|c|c|c|}
\hline & \multirow{2}{*}{\multicolumn{5}{|c|}{ Export Index }} & \multicolumn{10}{|c|}{ Contribution to Export Index ( in \%) } \\
\hline & & & & & & \multicolumn{5}{|c|}{ Supply Capacity Growth } & \multicolumn{5}{|c|}{ Foreign Market Acess Improvenent } \\
\hline & $\begin{array}{c}1994- \\
1996\end{array}$ & $\begin{array}{c}1996- \\
1998\end{array}$ & $\begin{array}{c}1998- \\
2000\end{array}$ & $\begin{array}{c}2000- \\
2002\end{array}$ & $\begin{array}{l}2002- \\
2004\end{array}$ & $\begin{array}{c}1994- \\
1996\end{array}$ & $\begin{array}{c}1996- \\
1998\end{array}$ & $\begin{array}{l}1998- \\
2000\end{array}$ & $\begin{array}{l}2000- \\
2002\end{array}$ & $\begin{array}{l}2002- \\
2004\end{array}$ & $\begin{array}{c}1994- \\
1996\end{array}$ & $\begin{array}{c}1996- \\
1998\end{array}$ & $\begin{array}{c}1998- \\
2000\end{array}$ & $\begin{array}{l}2000- \\
2002\end{array}$ & $\begin{array}{l}2002- \\
2004\end{array}$ \\
\hline Czech Republic & 1.31 & 1.31 & 1.37 & 1.29 & 1.33 & 93.6 & 41.4 & 45.4 & 37.9 & 19.4 & 6.4 & 58.9 & 54.6 & 62.1 & 80.6 \\
\hline Estonia & 1.48 & 1.77 & 1.43 & 1.08 & 1.05 & 94.1 & 68.9 & 48.1 & 44.5 & 12.2 & 5.9 & 31.1 & 51.9 & 55.5 & 87.8 \\
\hline Hungary & 1.15 & 2.01 & 1.50 & 1.19 & 1.21 & 91.9 & 49.8 & 44.1 & 37.6 & 21.2 & 8.1 & 50.2 & 55.9 & 62.4 & 78.8 \\
\hline Lithuania & 1.51 & 1.28 & 1.24 & 1.41 & 1.29 & 93.5 & 71.1 & 44.2 & 30.0 & 32.5 & 6.5 & 28.9 & 55.8 & 70.0 & 67.5 \\
\hline Latvia & 1.35 & 1.44 & 1.24 & 1.21 & 1.27 & 93.5 & 71.2 & 44.4 & 30.1 & 33.0 & 6.5 & 28.8 & 55.6 & 69.9 & 67.0 \\
\hline Poland & 1.35 & 1.31 & 1.36 & 1.27 & 1.39 & 93.2 & 42.4 & 49.1 & 36.5 & 22.2 & 6.8 & 57.6 & 50.9 & 63.5 & 77.8 \\
\hline Slovakia & 1.35 & 1.34 & 1.36 & 1.22 & 1.44 & 99.4 & 41.7 & 49.4 & 33.7 & 30.0 & 0.6 & 58.3 & 50.6 & 66.3 & 70.0 \\
\hline Slovenia & 1.16 & 1.21 & 1.18 & 1.15 & 1.17 & 94.9 & 50.7 & 40.0 & 35.0 & 22.6 & 5.1 & 49.3 & 60.0 & 65.0 & 77.4 \\
\hline Bulgaria & 1.07 & 0.98 & 1.44 & 1.15 & 1.32 & 88.1 & 40.2 & 73.9 & 35.9 & 24.2 & 11.9 & 59.8 & 26.1 & 64.1 & 75.8 \\
\hline Croatia & 1.00 & 1.12 & 1.18 & 1.08 & 1.24 & 90.5 & 45.9 & 37.7 & 34.8 & 21.2 & 9.5 & 54.1 & 62.3 & 65.2 & 78.8 \\
\hline Romania & 1.25 & 1.17 & 1.55 & 1.31 & 1.29 & 90.4 & 44.2 & 43.1 & 38.2 & 22.5 & 9.6 & 55.8 & 56.9 & 61.8 & 77.5 \\
\hline Albania & 1.40 & 1.12 & 1.52 & 1.28 & 1.36 & 82.3 & 84.7 & 1.0 & 52.8 & 24.9 & 17.7 & 15.3 & 99.0 & 47.2 & 75.1 \\
\hline Macedonia & 1.04 & 1.28 & 1.23 & 0.82 & 1.11 & 83.8 & 84.1 & 0.9 & 53.2 & 23.5 & 16.2 & 15.9 & 99.1 & 46.8 & 76.5 \\
\hline Serbia and Montenegro & 1.00 & 1.00 & & 1.31 & 1.30 & 83.2 & 84.6 & & 53.0 & 24.8 & 16.8 & 15.4 & & 47.0 & 75.2 \\
\hline NMS-8 & 1.33 & 1.46 & 1.34 & 1.23 & 1.27 & 94.3 & 55.0 & 45.7 & 35.5 & 24.5 & 5.7 & 45.0 & 54.3 & 64.5 & 75.5 \\
\hline CC-3 & 1.11 & 1.09 & 1.39 & 1.18 & 1.28 & 89.7 & 43.6 & 52.2 & 36.4 & 22.7 & 10.3 & 56.4 & 47.8 & 63.6 & 77.3 \\
\hline SEE-3 & 1.22 & 1.20 & 1.37 & 1.14 & 1.26 & 82.9 & 84.4 & 0.9 & 53.0 & 24.5 & 17.1 & 15.6 & 99.1 & 47.0 & 75.5 \\
\hline All countries & 1.24 & 1.31 & 1.36 & 1.20 & 1.27 & 91.2 & 58.5 & 40.3 & 39.2 & 24.1 & 8.8 & 41.5 & 59.7 & 60.8 & 75.9 \\
\hline
\end{tabular}

Table 4.

Export Growth and Relative Contribution of Supply Capacity and Foreign Market Access Growth to Export Growth of NMS-8, CC-3 and SEE-3, 1994-2004

Notes: Bi-annual index of growth of exports, supply capacity and foreign market access, calculated from equations (2)

and (3). Supply capacity and foreign market access growth are then recalculated so as to show their relative contribution

to the growth of exports.

pacity and foreign market access are remarkably uniform across individual transition countries. There is some variation in the export figures around the common increasing trend of exports. The exception is the SEE-3, where oscillations are much higher and more persistent than those of other countries. Table 4 further demonstrates some differences in export performance within the transition countries. Over the periods of 1994-96, 1996-98 and 2000-2002, the group NMS-8 has increased its exports at a faster pace (33\%, 46\% and 23\% respectively) than the CC-3 (11\%, 9\% and $18 \%$ respectively) and the SEE-3 (22\%, 20\% and 14\% respectively). In the last analysed period of 2002-2004, all three groups of countries converged at similar growth rates for exports $(27 \%, 28 \%$ and $26 \%$ in terms of bi-annual growth rates).

Table 4 shows that the contribution of foreign market access to transition countries export growth has been constantly increasing and vice versa is true for supply capacity. Until 1998, supply capacity increase was more important for export growth than foreign market access improvements, yet later on the situation changed. If over 1994-96 the contribution of improved foreign market access to the export growth of transition countries was only $8.8 \%$ and of supply capacity growth as much as $91.2 \%$, by $2002-04$ the contribution of market access increased to $75.9 \%$ and of supply capacity decreased to $24.1 \%$. It seems that the opening up of foreign markets for transition countries has needed quite some time before producing genuine impact. This is true for all three groups of transition countries. ${ }^{10}$

Over the period 1994-2000, there were considerable differences among individual groups of countries in terms of the respective contribution of market access and supply capacity. As time passed, the differences diminished. Between 2002-2004 there were almost no differences in terms of export growth (export index of 1.27, 1.28 and 1.26, respectively for NMS-8, CC-3 and SEE-3), the contribution of foreign market access $(75.5 \%, 77.3 \%$ and $75.5 \%$, respectively) and supply capacities $(24.5 \%, 22.7 \%$ and $24.5 \%$, respectively).

The data suggest that, until 2004, the NMS-8, CC-3 and SEE3 have become very similar in terms of the contribution of foreign market access to their export growth. Further disaggregating of foreign market access to individual groups of importing countries, however, shows considerable differences between transition countries. Table 5, which decomposes foreign market access into five regional components (EU-15, NMS-8, Cyprus and Malta, CC-3, non-EU OECD countries, and SEE), demonstrates that access to the EU-15 has contributed much more to the overall market access growth of the NMS-8 as compared to the CC-3. On the

${ }_{10}$ There are some irregularities in the trends for the SEE-3, which is due to problems with the data 


\begin{tabular}{|c|c|c|c|c|c|c|c|c|c|c|c|c|c|c|c|}
\hline & \multicolumn{15}{|c|}{ Contribution of } \\
\hline & \multicolumn{5}{|c|}{ EU - 15} & \multicolumn{5}{|c|}{ NMS-8, Cyprus and Malta } & \multicolumn{5}{|c|}{ CC-3 } \\
\hline & $\begin{array}{c}1994- \\
1996\end{array}$ & $\begin{array}{c}1996- \\
1998\end{array}$ & $\begin{array}{l}1998- \\
2000\end{array}$ & $\begin{array}{l}2000- \\
2002\end{array}$ & $\begin{array}{c}2002- \\
2004\end{array}$ & $\begin{array}{c}1994- \\
1996\end{array}$ & $\begin{array}{c}1996- \\
1998\end{array}$ & $\begin{array}{l}1998- \\
2000\end{array}$ & $\begin{array}{c}2000- \\
2002\end{array}$ & $\begin{array}{l}2002- \\
2004\end{array}$ & $\begin{array}{c}1994- \\
1996\end{array}$ & $\begin{array}{c}1996- \\
1998\end{array}$ & $\begin{array}{c}1998- \\
2000\end{array}$ & $\begin{array}{c}2000- \\
2002\end{array}$ & $\begin{array}{l}2002- \\
2004\end{array}$ \\
\hline Czech Republic & 73.7 & 76.7 & 73.9 & 73.1 & 73.0 & 8.5 & 8.5 & 10.6 & 11.4 & 13.2 & 1.1 & 1.2 & 1.4 & 1.6 & 2.2 \\
\hline Estonia & 90.7 & 90.1 & 89.7 & 90.1 & 86.7 & 2.9 & 3.5 & 4.2 & 4.2 & 6.4 & 0.1 & 0.2 & 0.2 & 0.2 & 0.4 \\
\hline Hungary & 51.2 & 55.8 & 54.5 & 52.8 & 53.9 & 12.0 & 12.2 & 15.0 & 16.1 & 18.3 & 2.5 & 2.9 & 2.9 & 3.4 & 5.0 \\
\hline Lithuania & 50.1 & 54.1 & 54.4 & 52.3 & 53.0 & 16.0 & 16.6 & 18.7 & 20.5 & 23.5 & 0.9 & 1.0 & 1.1 & 1.3 & 1.9 \\
\hline Latvia & 61.5 & 63.8 & 63.6 & 62.0 & 60.5 & 15.3 & 15.8 & 17.6 & 19.3 & 22.4 & 0.5 & 0.6 & 0.7 & 0.8 & 1.2 \\
\hline Poland & 58.8 & 62.1 & 62.2 & 60.4 & 60.1 & 13.1 & 13.4 & 15.7 & 17.1 & 19.8 & 1.3 & 1.4 & 1.6 & 1.8 & 2.5 \\
\hline Slovakia & 88.4 & 88.8 & 86.2 & 86.5 & 84.0 & 4.2 & 4.6 & 6.1 & 6.2 & 8.4 & 0.6 & 0.7 & 0.9 & 1.0 & 1.5 \\
\hline Slovenia & 58.8 & 63.6 & 61.4 & 58.9 & 59.8 & 6.8 & 6.8 & 9.0 & 9.4 & 10.5 & 10.0 & 10.3 & 9.7 & 12.1 & 14.6 \\
\hline Bulgaria & 19.1 & 24.7 & 27.3 & 25.0 & 31.3 & 2.2 & 2.6 & 4.0 & 4.0 & 5.6 & 1.9 & 2.4 & 2.6 & 3.0 & 4.8 \\
\hline Croatia & 40.9 & 44.6 & 46.5 & 44.0 & 44.9 & 19.3 & 19.9 & 22.9 & 25.0 & 28.0 & 0.6 & 0.7 & 0.8 & 0.9 & 1.3 \\
\hline Romania & 28.8 & 34.5 & 37.1 & 34.7 & 39.4 & 3.8 & 4.4 & 5.7 & 6.0 & 7.8 & 3.6 & 4.4 & 4.2 & 5.1 & 7.5 \\
\hline Albania & & & & & & 2.7 & 3.4 & 5.3 & 5.0 & 7.3 & 7.6 & 9.1 & 11.6 & 12.9 & 18.6 \\
\hline Macedonia & & & & & & 4.6 & 5.6 & 8.2 & 7.8 & 10.5 & 11.8 & 14.8 & 15.3 & 17.4 & 25.5 \\
\hline Serbia and Montenegro & & & & & & & & & 5.1 & 7.7 & & & & 11.4 & 18.8 \\
\hline NMS-8 & 63.8 & 69.8 & 68.3 & 66.3 & 66.9 & 10.8 & 9.7 & 12.0 & 13.4 & 15.1 & 1.9 & 2.3 & 2.3 & 2.7 & 3.6 \\
\hline CC-3 & 28.6 & 34.7 & 38.7 & 34.4 & 38.5 & 7.5 & 9.0 & 11.8 & 11.3 & 13.7 & 2.1 & 2.5 & 2.6 & 3.1 & 4.5 \\
\hline SEE-3 & & & & & & 3.5 & 4.6 & 6.6 & 5.7 & 8.4 & 9.3 & 12.2 & 13.2 & 13.4 & 20.7 \\
\hline All countries & 39.6 & 61.7 & 49.5 & 54.9 & 54.9 & 7.3 & 8.4 & 9.8 & 10.4 & 11.9 & 3.9 & 2.6 & 4.7 & 3.9 & 6.5 \\
\hline \multirow[t]{3}{*}{ TABLE 5; Continuation } & \multicolumn{15}{|c|}{ Contribution of } \\
\hline & \multicolumn{5}{|c|}{ Non-EU OECD countries } & \multicolumn{5}{|c|}{ South East Europe } & \multicolumn{5}{|c|}{ TOTAL } \\
\hline & $\begin{array}{c}1994- \\
1996\end{array}$ & $\begin{array}{c}1996- \\
1998\end{array}$ & $\begin{array}{l}1998- \\
2000\end{array}$ & $\begin{array}{c}2000- \\
2002\end{array}$ & $\begin{array}{l}2002- \\
2004\end{array}$ & $\begin{array}{c}1994- \\
1996\end{array}$ & $\begin{array}{c}1996- \\
1998\end{array}$ & $\begin{array}{l}1998- \\
2000\end{array}$ & $\begin{array}{l}2000- \\
2002\end{array}$ & $\begin{array}{l}2002- \\
2004\end{array}$ & $\begin{array}{c}1994- \\
1996\end{array}$ & $\begin{array}{c}1996- \\
1998\end{array}$ & $\begin{array}{l}1998- \\
2000\end{array}$ & $\begin{array}{l}2000- \\
2002\end{array}$ & $\begin{array}{l}2002- \\
2004\end{array}$ \\
\hline Czech Republic & 13.0 & 10.7 & 11.0 & 10.8 & 9.1 & 3.7 & 3.0 & 3.1 & 3.1 & 2.5 & 100.0 & 100.0 & 100.0 & 100.0 & 100.0 \\
\hline Estonia & 5.6 & 5.6 & 5.3 & 4.9 & 5.7 & 0.6 & 0.6 & 0.6 & 0.6 & 0.7 & 100.0 & 100.0 & 100.0 & 100.0 & 100.0 \\
\hline Hungary & 27.9 & 23.8 & 22.1 & 22.2 & 18.4 & 6.5 & 5.3 & 5.6 & 5.5 & 4.3 & 100.0 & 100.0 & 100.0 & 100.0 & 100.0 \\
\hline Lithuania & 29.1 & 24.9 & 22.6 & 22.8 & 19.0 & 3.9 & 3.3 & 3.2 & 3.2 & 2.7 & 100.0 & 100.0 & 100.0 & 100.0 & 100.0 \\
\hline Latvia & 20.1 & 17.5 & 16.0 & 15.8 & 13.9 & 2.5 & 2.2 & 2.2 & 2.1 & 1.9 & 100.0 & 100.0 & 100.0 & 100.0 & 100.0 \\
\hline Poland & 24.0 & 20.7 & 18.3 & 18.5 & 15.8 & 2.8 & 2.3 & 2.3 & 2.3 & 1.8 & 100.0 & 100.0 & 100.0 & 100.0 & 100.0 \\
\hline Slovakia & 5.2 & 4.7 & 5.3 & 4.9 & 4.8 & 1.5 & 1.3 & 1.5 & 1.4 & 1.4 & 100.0 & 100.0 & 100.0 & 100.0 & 100.0 \\
\hline Slovenia & 21.0 & 16.7 & 17.1 & 16.9 & 13.0 & 3.4 & 2.7 & 2.8 & 2.7 & 2.1 & 100.0 & 100.0 & 100.0 & 100.0 & 100.0 \\
\hline Bulgaria & 28.8 & 27.6 & 26.8 & 26.7 & 24.7 & 48.1 & 42.7 & 39.4 & 41.3 & 33.6 & 100.0 & 100.0 & 100.0 & 100.0 & 100.0 \\
\hline Croatia & 31.6 & 28.3 & 23.5 & 23.9 & 20.7 & 7.6 & 6.4 & 6.4 & 6.3 & 5.1 & 100.0 & 100.0 & 100.0 & 100.0 & 100.0 \\
\hline Romania & 45.7 & 41.4 & 37.8 & 38.6 & 33.1 & 18.1 & 15.3 & 15.2 & 15.6 & 12.1 & 100.0 & 100.0 & 100.0 & 100.0 & 100.0 \\
\hline Albania & 15.9 & 16.1 & 18.2 & 16.6 & 15.3 & 73.8 & 71.4 & 64.8 & 65.5 & 58.8 & 100.0 & 100.0 & 100.0 & 100.0 & 100.0 \\
\hline Macedonia & 49.1 & 44.7 & 46.3 & 44.3 & 35.3 & 34.5 & 34.8 & 30.3 & 30.5 & 28.8 & 100.0 & 100.0 & 100.0 & 100.0 & 100.0 \\
\hline Serbia and Montenegro & & & & 19.7 & 17.2 & & & & 63.7 & 56.3 & 100.0 & 100.0 & 100.0 & 100.0 & 100.0 \\
\hline NMS-8 & 20.1 & 15.4 & 14.7 & 14.9 & 12.2 & 3.3 & 2.8 & 2.7 & 2.6 & 2.2 & 100.0 & 100.0 & 100.0 & 100.0 & 100.0 \\
\hline CC-3 & 35.5 & 32.7 & 30.4 & 30.1 & 26.2 & 26.3 & 21.1 & 16.5 & 21.2 & 17.0 & 100.0 & 100.0 & 100.0 & 100.0 & 100.0 \\
\hline SEE-3 & 29.4 & 31.5 & 30.7 & 24.3 & 21.8 & 57.9 & 51.7 & 49.4 & 56.5 & 49.1 & 100.0 & 100.0 & 100.0 & 100.0 & 100.0 \\
\hline All countries & 25.1 & 18.5 & 20.1 & 17.4 & 15.3 & 24.1 & 8.8 & 15.8 & 13.3 & 13.4 & 100.0 & 100.0 & 100.0 & 100.0 & 100.0 \\
\hline
\end{tabular}

\section{Table 5.}

Contributions of Individual Country Groups to Foreign Market Access Growth of NMS-8, CC-3 and SEE-3, 1994-2004 (in \%) Note: Contribution of individual groups of countries is calculated from bi-annual index of growth of foreign market access

from equation (3), weighted by the share of individual group of countries in total exports.

other hand, the contribution of the EU-15 to the growth of

the overall market access of the CC-3 is gradually increasing, while in the case of the NMS-8 it has stagnated at high levels. Obviously, the EU integration process is an important determinant of market access to the EU-15, and one can expect that the CC-3 and the SEE-3 will further benefit from this process in the future. The non-availability of data does not allow us to make any conclusions about the actual importance of EU-15 market access for the SEE-3. What is obvious is that market access for South East Europe has made an important contribution to their overall market access growth. This may even increase in the future, due to the recent particpation of South East European countries in the CEFTA.

The main question of our exercise concerned the importance of EU-15 market access to the export performance of transition countries. The answer is that market access growth represents the main determinant of export growth for all the groups of transition countries. Additionally, the 
importance of market access growth for the export growth of these countries is constantly increasing. In terms of market access growth, the EU-15 contribute the main part, about two thirds in the case of the NMS- 8 and almost 40\% in the case of the CC-3. Better EU-15 market access can then largely explain the better export performance of the NMS-8. Further EU integration processes may bring similar benefits to the CC-3 and the SEE-3.

\section{Conclusion}

This paper looked at changes in EU market access and the impressive growth in export performance among transition countries. Based on the relevant theoretical concepts, we follow the approach of Redding and Venables (2003, 2004), and Fugazza (2004), which decompose the export performance of individual countries into foreign market access and internal supply capacity components. More precisely, we build an econometric gravity-type model to assess the contributions of market access (in general and to EU-15) versus supply capacity improvement to increasing the export performance of transition countries. We find that the contribution of foreign market access to transition countries export growth has been constantly increasing and vice versa is true for supply capacity. Until 1998, supply capacity increase was more important for export growth than foreign market access improvements, yet later on the situation changed. Until 2004, the NMS8, CC-3 and SEE-3 have become very similar in terms of the contribution of foreign market access to their export growth. This is not the case however, where market access to the EU-15 is concerned. Improving access to EU-15 markets has been much more important to the overall foreign market access growth of the NMS-8 as opposed to the CC-3.

To answer the question of how important EU-15 market access has been for the improved export performance of transition countries several assertions can be made. Market access growth represents the main determinant of export growth among all the groups of transition countries reviewed in this paper. Additionally, the importance of foreign market access growth for the export growth of transition countries is constantly increasing. In terms of market access growth, the EU-15 contribute the better part, about two thirds in the case of the NMS-8 and almost 40\% in the case of the CC-3. Better EU-15 market access then can largely explain the better export performance of the NMS-8. Further EU integration pro(…es may bring similar benefits to the CC-3 and the SEE-3.

\section{References}

Baldwin, R.E. 1994. Towards an Integrated Europe. London: CEPR.

Bussiere, M., J. Fidrmuc and B. Schantz. 2005. Trade Integration of Central and Eastern European Countries: Lessons from a Gravity Model. Working Paper Series No. 545 (November). Frankfurt: European Central Bank.

Collins, S. and D. Rodrik. 1991. Eastern Europe and the Soviet Union in the World Economy. Washington, D.C.: Institute for International Economics.EBRD. 2005. Transition Report 2005. London: EBRD.

Egger, P. 2003. An econometric view on the estimation of gravity models and the calculation of trade potentials. The World Economy, 25(2): 297-312.

Fidrmuc, J and J. Fidrmuc. 2003. Disintegration and trade. Review of International Economics, 11(5): 811-829.

Fugazza, M. 2004. Export Performance and Its Determinants: Supply and Demand Constraints. Policy Issues in International Trade and Commodities Study Series No. 26. New York and Geneva: United Nations Conference on Trade and Development (UNCTAD).

Halpern, L. 2002. International Trade, Competitiveness and Catching Up in Transition Countries - Some Recent Developments and Policies for Improvement. In V. Benaček and J. Gacs (eds.), Catching Up and EU Accession - Conditions for Fast Real Convergence in the Candidate Countries. Interim Report IR-02-068/October. Laxenburg: IIASA. Pp. 59-63.

Hamilton, C.B. and A.L. Winters. 1992. Opening up International Trade for Eastern Europe. Economic Policy, April: 78-115.

Havlik, P. 2000. Trade and Cost Competitiveness in the Czech Republic, Hungary, Poland and Slovenia. World Bank Technical Paper No. 482 (November). Washington, D.C.: World Bank.

Havlik, P., M. Landesmann and R. Stehrer, R. 2001. Competitiveness of CEE Industries: Evidence from foreign Trade Specialization and Quality Indicators. WIIW Research Reports, No. 278 (July). Vienna: The Vienna Institute for International Economic Studies.

Havrylyshyn and Al-Atrash. 1998. Opening Up and Geographic Diversification of Trade in Transition Economies. IMF Working Paper, WP/98/22. Washington, D.C.: International Monetary Fund, European II and Policy Development and Review Departments. 
Havrylyshyn, O and Pritchett. 1991. European Trade Patterns after the Transition. Policy, Research and External Affairs, Working Papers, Trade Policy, WPS 748. Washington, D.C.: World Bank.

IMD. 2004. IMD World Competitiveness Yearbook 2004. Lausanne: Institute for Management Development.

Jakab, Z., M.A. Kovacs and A. Oszlay. 2001. How far has trade integration advanced? An Analysis of the actual and potential trade of three Central and Eastern European countries. Journal of Comparative Economics, 29(2): 276-292.

Kaminski, B. 1994. The Significance of the Europe Agreements for central European Industrial Exports. Policy Research Working Paper 1314. Washington, D.C.: World Bank, International Economics Department, International Trade Division.

Kaminski, B., Z.K. Wang and L.A. Winters. 1996a. Trade performance, Export Reorientation in the Transition. Economic Policy, October, 421-442.

Kaminski, B., Z.K. Wang and L.A. Winters. 1996b. Foreign Trade in The Transition: The International Environment and Domestic policy. Studies of Economies in Transformation, No. 20. Washington, D.C.: World Bank.

Mongelli, F.P., E. Dorrucci and I. Agur. 2005. What Does European Institutional Integration Tell Us about Trade Integration? Occasional Paper Series, No. 40 (December). Frankfurt: European Central Bank.

Redding, Stephen and Anthony J. Venables. 2004. Economic Geography and International Inequality. Journal of International Economics, 62(1): 53-82.

Redding, Stephen and Anthony J. Venables. 2003. Geography and Export Performance: External Market Access and Internal Supply Capacity. NBER Working Paper Series, Working Paper 9637. Cambridge, MA.: National Bureau of Economic Research (NBER).

Rivera-Batiz, Luis A. and Maria-Angels Olive. 2003. International Trade: Theory, Strategies and Evidence. New York: Oxford University Press.

Rojec, M. and M. Ferjančič. 2006. Overview of Export Performance of "New Europe": Theoretical Underpinnings and Empirical Evidence. The Second Lancut Economic Forum: The Competitiveness of New Europe, 28-29, April. Lancut: Polish Society of Economists and Rzeszow University of Information Technology and Management.

Rosati, D. 1992. Problems of Post-CMEA Trade and Payments. Discussion Paper 650. London: Center for Economic Policy Research.
WEF (World Economic Forum). 2004. The Global Competitiveness Report 2004-2005. New York, Oxford: Oxford University Press.

Zinnes, C., Y. Eilat and J. Sachs. 2001. Benchmarking competitiveness in transition economies. Economics of Transition, 9(2): 315-353. 